Volume: 13 Issue: 3 Year: 2016

\title{
Consumption culture and body in cinema context: Fight Club
}

\author{
Özlem Aydoğmuş Ördem ${ }^{1}$
}

\begin{abstract}
Studies on consumption culture and body have been examined considerably in sociology in recent years. Analysis of culture industry through cinema can be viewed as an important practice in understanding sociological theories and concepts. This study examined the movie Fight Club through content analysis within the framework of consumption culture and body. The present study found that the movie contained the concepts of desire, ambivalence, chronic health problems, and transition from the world of objects to discourse dimension, desire of destroying, principle of bodily desire and lack of reciprocal relationship and showed that there was a significant relationship between the concepts in the movie and sociological theories. The study indicated that sociological analysis of the movie Fight Club could be evaluated as a crucial tool in the analysis of sociological problems.
\end{abstract}

Keywords: Consumption culture; body; culture industry; cinema; Fight Club.

\section{Introduction}

Some concepts such as modernism, culture, ideology, culture industry have been identified in many forms from the $19^{\text {th }}$ century to the present. The critical philosophers in its modernist sense, from Rousseau to Foucault, accompanied the critique of both Enlightenment and capitalism. One of the most significant Enlighteners, Rousseau, thinks that the understanding of development which is far from the declaration of evil, cruelty, disasters in the human world bring harm rather than benefit human. Rousseau indicates that intelligence, science and technology are extremely important in the development of the society. He emphasises that the development can only be development as long as it allows people to liberate. He rejects any understanding of development apart from that. In this regard, Rousseauian structure is found in the intellectual background of the critical philosophers. Especially with the liberation of humankind, Rousseau's debatable approach to the relationship between intelligence, science and technology also intensely influences today's thinkers (Oskay, 1983). Marx is shown as a philosopher of modernism in many sources, especially in the work named All That is Solid Melts into Air by Marshall Berman. It is mentioned the fragmentation and razing of everything which is solid with modernism. Eventually in this regard, capitalism will be razed and be replaced by communism. In Weber's (1997) concept of modernism, it is mentioned that the modernism imprisons the humanity into the iron cage and breaks the current world's spell. Durkheim also sees the world as problematic and particularly criticizes industrialisation by indicating that it leads to anomy. Nietzsche evaluates the modern age within the context of the decadence of values and the collapse of Christianity, and he declares the victory of Nihilism. Rationalization, instrumental rationality, and wishing of dominate the nature come into

\footnotetext{
${ }^{1}$ Ph.D., Republic of Turkey Ministry of Justice, National Probation Service, ozlemordem@gmail.com
} 
prominence in the critics of modernism of Critical Theoreticians. Weber and Nietzsche have significant influence on the Critical Theoreticians. Foucault, on the other hand, was impressed by Nietzsche and Critical Theoreticians. It is particularly important in that it inverses the relationship which he builds between Enlightenment, modernism and liberty (Oskay, 1983).

In line with the explanations above, this study aims to discuss consumption culture within the soundly based framework of The Fight Club movie because this movie handles consumption cultural critically and in a way deconstructs what is taken for granted in a certain society. Thus, the main assumption of this paper is that societies can be interpreted through movies that are of artistic value in social sciences.

\section{Methodology}

In this study, The Fight Club movie was examined within the scope of Turner's body hypothesis, Bauman's view of Ambivalence and Adorno's the culture industry sociologically. The movie was analysed through the content analysis within the frame of sociological hypothesis. The relationship of consumer culture and body was analysed in Fight Club movie within the scope of research and the study is limited to only these two relations.

Krippendorff (2004) identified the content analysis as a research method which is used in order to obtain valid and meaningful results which are appropriate to a specific text or context. Similarly, Bilgin (2003) assesses the content analysis as a controlled effort of interpretation. According to Yıldırım and Şimşek (2006), who expressed the content analysis as examining the concepts and relationships that can be classified in a particular area by collecting data, the data should be approached within the conceptual framework and be arranged in accordance with the obtained concepts. The hypothesis or themes explaining the data should be identified. The movie was divided into 6 episodes, each of which was watched several times. Themes were extracted from each episode. Then, the parts of the movie were analysed according to theories and concepts mentioned above.

\subsection{Findings}

The results have shown that there is a relationship between consumer culture, body and sociological theories and concepts of the Fight Club movie. More specifically, the results obtained some conceptual findings such as desire, ambiguity, chronic health problems, the transition from the world of objects to the discourse dimension, the desire of destruction, the lack of relation between the principle of body's pleasure and reciprocity. The results have shown that concepts are in a significant relationship with the theories in sociology.

\subsection{Conceptual and Theoretical Findings of Fight Club}

The movie Fight Club released in 1999 was firstly written as a short story by Chuck Palahniuk and then directed by director David Fincher. It appeared in the period when the postmodern discussions and consumer culture in sociology were intensively discussed. The movie has attracted considerable attention around the world. The movie with its anarchists and the microfascism style is an idea that reflects the process beginning from post-1960 period to the terrorist attacks 2001. Moreover, the writer of the movie emphasized that American youth was the lost generation between 1965 and 1990 and set up a project of demolition with a Marxist and anarchists reaction. In fact, the beginning and the ending of the movie show similarities in terms of including demolition projects. However, body-society point of view is also reflected by making a critique of modern and consumption society when it is delved into details of the movie. 
Aydoğmuş Ördem, Ö. (2016). Consumption culture and body in cinema context: Fight Club. Journal of Human Sciences, 13(3), 5530-5536. doi:10.14687/jhs.v13i3.4129

The hero of the movie, Jack reflects the consumption culture marvellously with his lifestyle. As well as being obsessed with shopping, Jack sees himself as an unhealthy body. He indicates that anorexia nervosa, modern disease in women, appears as insomnia in men and he goes to a doctor. The doctor leads Jack to other group therapies involved in diseases chronic in society in order to make him feel relaxed and to show him what the real pain and disease are. The first part of the movie is based on the body and the disease. Jack works for consumption in capitalism and he actually acquires a modern illness. Jack's perspective changes to some extent by participating in the group therapy. However, Jack will not be satisfied with therapy groups. Taking a step further, he will meet with another project and participate in this project. Jack will actually proceed from discourse dimension to the other dimension to perceive his body. He will reach the last dimension and this dimension will in fact prepare his end. His never-ending desire will be violent. Jack will not be satisfied with discourse order and reciprocity (Turner, 2001). Before the group therapies, Jack leads a lifestyle addicted to the objects. Then, he proceeds to a discourse dimension-based lifestyle and is conscious of the change. However, Jack does not confine himself to objects. In the movie, chronic patients in the society get professional help in certain places. This process goes off with the conversations between individuals. However, Jack is not satisfied with this process and chooses a different process. Tyler's short and radical sentences appear more different and interesting to him. Jack moves with the paradigms of consumption society for a long time. After meeting Tyler, Jack joins a different process. He hears an anti-government expression for the first time and Tyler criticizes Jack's consumer lifestyle in a few sentences. One-quarter of the movie is based on the consumption culture and therapy groups. Jack tends to change the objects but he cannot take the pleasure he wishes in any way. He plunges into a continuous quest and lives consumption-oriented. In fact, as Deleuze says, capitalism gets the pleasure to the centre and gets this pleasure consumed. Deleuze and Guattari (1987) indicate that every creative potential and every important social movement arises from escapes not from conflicts and confusion between classes and social bases. Jack has an escape. He leads a simple life in a simple house. He sees the violence in this simple life and he objects to violence till the end. The debate and critics on modernity change Jack's life. However, living with a primitive reaction, he opposes every step for the demolition project which turns into a universal force with Tyler's contribution.

In the second part of the movie, Jack meets the character of Tyler and Tyler's sense of body and comes into a new world because the forgotten body comes to life again via Fight Club. Jack says in the movie: 'I loved my life. I loved that condo. I loved every stick of furniture. That was my whole life. Everything, the lamps, the chairs, the rugs were me. The dishes in the cabinets were me. The plants were me. The television was me.' After this critique, Jack fights with Tyler unexpectedly and feels different. Jack finds himself in the middle of the violence day by day. Jack is faced with a reciprocity fact which involves physical violence and he begins to question again. It can be seen as an action which is an expression of a violence-oriented anger, and it can be interpreted as a kind of feeling the body in its symbolic sense. Before giving the rules of Fight Club, Tyler strongly criticizes the modern life and indicates that they are quite angry.

No matter how much effort he puts in, he cannot be authentic alone. He consumes more and becomes more addicted to the objects (Diken et al., 2003). This is the situation of being connected to the pleasure principle. However, Tyler implies to Jack that there must be a social bond. This is the feeling of the body in this social bond. Tyler strongly indicates the body with a symbolic language. As the body cannot be felt in the consumption societies, Fincher gives particular importance to feel the body itself. Fincher portrays the gathering and fighting of people in an unusual way. However, this situation is not entirely a sharing because one of the aims is to feel the body again. The scar is perceived as positive and 'I don't want to die without any scars' said Jack because the scar is a part of the body. And in a sense, it reminds that there is a body you have because a healthy body is deactivated and numb. There is a positive correlation between the body and the scar for Fincher in the sense of recovery. 
Aydoğmuş Ördem, Ö. (2016). Consumption culture and body in cinema context: Fight Club. Journal of Human Sciences, 13(3), 5530-5536. doi:10.14687/jhs.v13i3.4129

Consumerism is negative in Fight Club, and the body is forgotten in a sense but the questions of what the good one is and which solution it offers are among the important questions and critiques (Diken et al., 2003) Mayhem, the project of destroying the system, is only for destruction and individuals obtain nothing from this project. Fincher and the writer of the movie Palahniuk discover the problem per se but the solution which Turner offers is not based on the principle of reciprocity because there are no words and languages in Fight Club and the body is in the limelight. It is represented in a different format because the scar is a reminder of the body. It is a project which contains only violence and destruction. Although the prominent term is the reciprocity principle for Turner, it cannot mention any principle of reciprocity in Fight Club in a real sense because individuals are not active in sharing apart from fighting. The process of the movie is displayed as Table 1.

Table 1

Parts of Movie and Conceptual/ Theoretical Analysis

\begin{tabular}{|c|c|c|}
\hline Parts & $\begin{array}{l}\text { Concepts of the Movie Editing } \\
\text { Process }\end{array}$ & Theoretical Comment \\
\hline 1. Part & Jack's consumer lifestyle & $\begin{array}{l}\text { Bauman, Modernism and } \\
\text { Consumption Society (2003) }\end{array}$ \\
\hline 2. Part & $\begin{array}{l}\text { Jack's searching for disease and } \\
\text { physical therapy }\end{array}$ & Turner $(1995 ; 2001)$ \\
\hline 3. Part & $\begin{array}{l}\text { Meeting Tyler and first critique on } \\
\text { the discourse dimension }\end{array}$ & $\begin{array}{l}\text { Horkheimer and Adorno } \\
(1996)\end{array}$ \\
\hline 4. Part & $\begin{array}{l}\text { Jack - Tyler } \\
\text { Tyler- Group discussion }\end{array}$ & $\begin{array}{l}\text { Severe criticism to } \\
\text { modernization and } \\
\text { intelligence (Horkheimer } \\
\text { and Adorno (1996) and } \\
\text { Baumann (2003) }\end{array}$ \\
\hline 5. Part & $\begin{array}{l}\text { Living with Tyler } \\
\text { Simple place, Principle of Pleasure, } \\
\text { simple life } \\
\text { Fight Club }\end{array}$ & $\begin{array}{l}\text { Deleuze and Guattari (1987) } \\
\text { Bataille, (1997) }\end{array}$ \\
\hline 6. Part & Mayhem Demolition Project & Bataille (1997) \\
\hline
\end{tabular}

Jack experiences a serious problem between the desire and his body because he experiences a shift from the desire to knowing his body. He quits his consumer lifestyle and chooses a new lifestyle. He discovers the body in this process which proceeds into the destruction of modern society. In fact, in a sense, this is anarchism. It moves from an individual level to the macro level. In fact, in post-modern theories especially in structuralist discourse, there is no act of vandalism for system or institutions at macro level unlike Marxist ideology. It aims to criticize specific institutions at discourse level by using different methods. After recognizing his body, Jack who goes through a discourse process in the first half of the movie finds himself in a different demolition project. His desire of consuming is pushed away into the background. The desire of knowing himself comes to light. The importance of the body and desire is well-known in modern structuralist thinking. Foucault $(1979 ; 1980)$ has a special insistence on questioning bodies in his approach of historical analysis. On the contrary, Foucault (1980) sees power as constructive and productive. The desire is created through power/information. However, the process of Jack is directly tilted to the destruction in the movie. He chases his own desire. Then, we see Jack chase the desire of destruction and impulse of control. Jack's positive feature is that he criticizes the entire process until the end of the movie and objects to the demolition project Mayhem, and he gives the message that this is not true to the audience. Jack is given as a role model living as critical in consumption 

13(3), 5530-5536. doi:10.14687/jhs.v13i3.4129

society and modernity. Criticizing many processes, he is driven to commit suicide and the audience understands that the solution of demolition which Tyler offers while criticizing the demolition project is not the right one.

\section{Discussion}

Turner (2001) indicates that sociology has a very important role in human sciences and criticizes that sociology omits the bodies when it deals with the society. He turns to a theory of body and society based on the Feuerbach, Marx and Foucault's thought. Turner (2001) argues that sciences cannot develop an important thought related to human body. Turner (2001) mentions two approaches related to body. Firstly, the body is the experience gained by someone. Phenomenology explores how the biological condition of the presence affects the daily life and organizations. Moreover, it explores the complicated relationships into which social processes and cultural framework and organic systems are built. The ones in the second approach take the body as an expression which mentions the social relations. They see the body as a system of symbols. In their view, the understanding of body movements brings social structure. The ones who support this tendency view the body as structuring the power and knowledge in society and a part of social discourse. For theorists who are in the first group, the body is independent of the discourse which represents it. In the second group's point of view, the body is based on the basis of discourse practices. On the other hand, Turner (2001) argues that these two different views can be united at minimum level. Some of the approaches related to the human body come to light with new approaches which merge under the name of port-modernism which becomes assertive in sociology from day to day. According to the post-modernism, the concept of health has changed its meaning.

Turner (2001) emphasizes that the pain is 'my pain' and the disease is 'my disease' in his study related to body and says that desire comes to light in a different way in the consumption society. This desire is reproduced by the owner of it. According to Turner, managing the society means managing the bodies. Being managed requires the regulation, and this regulation is the imposing of uniformity to the individuals.

The cinema as a cultural industry is one of the main subjects in the critiques of modernism. As well as confusing people, cultural production catches them vulnerably and turns them into the consumers who waive their self-determination (Zipes, 2005). In this regard, philosophers give the mass creation feature of culture prominence. Capitalist society is criticized. Furthermore, the importance of culture and ideology has drawn attention in the advanced industry or in other words, modern societies. The mass creation feature of culture and ideology is underlined. When criticizing the cultural industry, Adorno mentions the results of Enlightenment and placing the intelligence to the centre. He moves away from the sociological and philosophical bases. Adorno (2005) criticizes sharply the Enlightenment in order that it puts the intelligence to the centre. He demonstrates the results of the Enlightenment for the main reason for this critic. It is evaluated that the results of the Enlightenment are the self-destruction of intelligence and the self-destruction of the Enlightenment. The reason is the point where the Enlightenment brought the intelligence, in other words the extinction of the individual. That the intelligence is defined as tools which are used for achieving the aims creates a new form of sovereignty. The values such as male-dominant society, personal property, free enterprise, competitive economic structure, heterosexuality have been validated and glorified (Gönen, 2007). The totalitarian style which the collective followed mercilessly and the terror which it spread continued and the individuals standing up against took shelter in the integrity which they identified as another misguided. This integrity is an integrity which consists of the individuals themselves and they cannot affect. Individuals get lost in this integrity. It is expected the self-destruction of this integrity which the individuals involved in. Adorno and Horkheimer (1996), indicates that the individuals wait to be set on fire by the integrity which consists of the individuals themselves and they cannot affect, in this world with no exit. At 

13(3), 5530-5536. doi:10.14687/jhs.v13i3.4129

this point, Adorno and Horkheimer are in the middle of a deep pessimism. The individual who lost his soul is approaching to destroy both the integrity which he is in and him. In the framework of this thought, one of the movies criticizing its own system in a radical way in Hollywood is Fight Club. The individuals in Fight Club movie go through a different process and they discover their bodies again. Because they show a tendency not to be as bodies which are organized by the system. It symbolizes the return of basic pleasures and removing the intelligence from the centre. The individuals who are desperate in the system aim to destroy the system. They waft themselves to a world full of violence. Generally, modernism, intelligence and consumption culture are criticized severely in the movie. Some proposals are offered to the problem and in the end, we witness demolition Project.

\section{Conclusion}

Remaining under pressure and vague in modern system, the individuals whose bodies are controlled and the unemployed and the employees who are destined to be lost in capitalism embark on a different quest in order to get rid of this ambiguity which modernity bred (Baumann, 2003). The characters in the Fight Club embark on the demolition project with a micro-fascist and anarchic impulse at extremes. This project which Jack opposed from the beginning ended in his suicide because he feels stuck in both cases. He has gained awareness for the situation in the consumption society. Although Jack develops a solution in his way, he is not satisfied with therapy groups. In its basic sense, he decides to lead a simple lifestyle. Mayhem Project which turns into an anarchic structure is not a solution that he desires. He gets stuck between the consumption culture and the demolition project which he rejects, and commits a suicide because he is aware that this demolition project is not the right project. This case is similar to despair of Horkheimer and Adorno (1996) and both of them expect to be destroyed. However, when this work is viewed in a positive sense, Turner's (2001) reciprocity suggestion can be seen in therapies because the characters gain awareness of the conditions of his disease. The characters say that they are not scared of death which is the most extreme experience for an individual. Considering the diseases, the movie characters deal with chronic, acute and fatal illnesses, which normal individuals in the society see as an anomy.

The movie is a criticism of consumption society and modernity in its real sense. The body in the society is highlighted due to the fact that it deals with disease. With an approach which can be called the psychoanalytic and psychological (Turner, 2001), the movie is in search of a solution which is based on the reciprocity relation to the disease problem. The anarchic and terroristic demolitions projects beginning from 1960's are criticized till the end via Jack and the solution of the movie is given through the therapy groups in the first part of it. However, the end of the movie harshly criticizes the system and brings a radical solution containing severe violence which engulfs the whole movie symbolically or physically. The solution, in this sense, may not be realistic. However, the helplessness of the world is explained with a world collapsing and being destroyed. Jack's and Tyler's attempts to become actual, authentic, critical and resisting subjects in a given consumption society come to a hopeless halt in a way how Adorno conceptualizes the world pessimistically because subjects in this kind of bureaucratic and technocratic world with an emphasis on consumption can be merely in the past while living the present bodily.

\section{References}

Adorno, T. W. (2005). 'Kültür Endüstrisini Yeniden Düşünmek, Adorno', (E. Mutlu çev.), E. Mutlu (Der.), Kitle İletişim Kuramlar (1. Basım) içinde (240-249), Ankara: Ütopya Yayınevi.

Bataille, G. (1997). 'Programme (Relative to Acephale)'. In Botting, F. And Wilson, S, The Bataille reader, London: Blackwell, 
Aydoğmuş Ördem, Ö. (2016). Consumption culture and body in cinema context: Fight Club. Journal of Human Sciences, 13(3), 5530-5536. doi:10.14687/jhs.v13i3.4129

Bauman, Z. (2003). Modernlik ve Müphemlik, (Çev: İsmail Türkmen).İstanbul: AyrıntıYayınları.

Berman, M. (2008). Katı olan her şey buharlassyyor: (Cevirenler Ümit Altuğ, Bülent Peker). İstanbul: İletişim Yayınlar1.

Bilgin, N. (2003). Sosyal Psikoloji Sözlüğü - Kavramlar, Yaklaşımlar. İstanbul: Bağlam Yayınları.

Deleuze, G., \& Guattari, F. (1987). A Thousand Plateus. Capitalism and Schirophrenia II. Minneapolis and London: University of Minneapolis Press.

Diken, B., Casten, B. L., Nefes, T. (2003). 'Postmodern şiddet: Network toplumunda dövüş kulübü', Doğu Bat1, 6 (23), 263-283.

Foucault, M. (1979). Cinselligin Taribi, Londra: Penguin Yayınevi.

Foucault, M. (1980). İktidat/Bilgi, Brighton: Harvester Yayınevi.

Gönen, M. (2007). Hollywood Sineması, İstanbul: Es Yayınları.

Horkheimer, M. ve Adorno, T. W. (1996). Aydinlanmanm Diyalektiüi Felsefi Fragmanlar-1, İstanbul: Kabalc1 Yayınevi.

Krippendorff, K. (2004). Content Analysis: An Introduction To Its Methodology. New York: Sage Publication.

Oskay, Ü. (1983). 'Popüler Kültürün Toplumsal Ortamı ve ideolojik işlevleri Üzerine', K. Alemdar ve R. Kaya (Der.), Kitle İletişiminde Temel Yaklaşımlar (1. Basım) içinde (163-206), Ankara: Savaş Yayınevi.

Turner, B. S. (1995), Tzbbi Güc ve Sosyal Bilgi, Londra: Sage Yayınlar1.

Turner, B. S. (2001). Beden ve Toplum, Londra: Sage Yayınlar1

Weber, M. (1997). Sosyoloji Yą̨lar, (T. Parla çev.), İstanbul: Hürriyet Vakfi.

Yıldırım, A. \& Şimşek, H. (2006). Sosyal bilimlerde nitel araştırma yöntemleri. Ankara: Seçkin Yayıncilık.

Zipes, J. (2005). 'Frankfurt Okulu ve Kültür Eleştirisi', E. Mutlu (Der.), Kitle İletişim Kuramlar (1. Basım) içinde (227-232), Ankara: Ütopya Yayınları. 